\title{
Provocation of allergic response by supplementary feeds of cows' milk
}

\author{
S A ROBERTS AND J F SOOTHILL \\ John Radcliffe Hospital, Oxford, and Institute of Child Health, London
}

SUMMARY The postweaning IgE and IgG antiovalbumin antibody responses were greater in rat pups which had received a cows' milk-based supplementary feed than in litter mates which had not. This effect was antigen non-specific and might be similar to that of supplementary feeds in the development of atopy in human infants. The total IgE concentration was similar in the two groups. Supplementary feeds did not increase the low values of IgE antiovalbumin in rats suckled by mothers immunised to ovalbumin.

Prospective studies show that exclusive breast feeding protects genetically-predisposed human infants from developing eczema and other atopic allergies. ${ }^{12}$ The mechanism is not known but it is likely to be more complicated than simply avoidance of antigens, and there is reason to believe that it is antigen-non-specific, influencing the responses to many antigens. ${ }^{34}$ After showing that milk of ovalbumin-sensitised mothers suppressed the IgE antibody response in suckled young Hooded Lister (HL) rats, ${ }^{5}$ Jarrett and Hall suggested that this might explain the observation in human atopics, but this is doubtful as the effect in rats is antigen specific. We have therefore investigated the effect of feeding supplements of a cows' milk preparation to HL rat pups on their subsequent IgE and IgG responses to ovalbumin, to see if the supplements produce an antigen-non-specific effect on IgE responses.

\section{Methods}

Serum IgE antiovalbumin was determined by the paper radioallergosorbent method of Karlsson et $a .^{6}$ using rabbit anti-rat $\mathrm{Fc}^{\mathrm{E}}$. Results were expressed as counts bound by sample/counts bound by newborn rat serum. Agglutinating antiovalbumin antibodies in sera, absorbed with $50 \%$ washed human red cells were assayed by chromic chloridetreated ovalbumin-coated human red cells. ${ }^{7}$ Sera, with or without pretreatment with dithiothreitol which inactivates $\operatorname{IgM},{ }^{8}$ were titrated by doubling dilutions on microtitre plates. Results are expressed as $-\log ^{2}$ titre. Total serum $\mathrm{IgE}(\mathrm{ng} / \mathrm{ml})$ was determined by a paper radioimmunosorbent method ${ }^{6}$ using a standard curve of dilutions of rat IgE myeloma of known concentrations.
The immunisation regimen was modified from Jarrett and Hall. ${ }^{5}$ To determine the optimum antigen dose for IgE response in young HL (Animal Suppliers or OLAC*) rats, each rat was injected intraperitoneally with $0 \cdot 1,1 \cdot 0,10,100$, and $1000 \mu \mathrm{g}$ of ovalbumin in saline with $10^{6}$ heat-killed Bordetella pertussis as adjuvant on day $23 ; 1.0 \mu \mathrm{g}$ in saline was given intraperitoneally at day 50 , and the rat was bled by cardiac puncture 4 days later. The highest IgE antibody responses were to 1.0 and $10 \mu \mathrm{g}$, and these doses and this regimen was used throughout the study.

Litters were divided into supplemented and control groups. From the third day of life until weaning at 21 days, each rat in the supplemented group was separated from its lactating mother for 12 hours a day, and gavaged with $0.1 \mathrm{ml} / \mathrm{g}$ of a feed based on Cow and Gate Premium infant feed daily in divided doses; this is equivalent to half the nutritional requirement. ${ }^{9}$ The preparation contained dried cows' milk $(120 \mathrm{~g} / \mathrm{l})$, casein $(70 \mathrm{~g} / \mathrm{l})$, and $20 \%$ arachis oil emulsion (Prosparol), providing $160 \mathrm{cal} / 100 \mathrm{ml}$. On this regimen several (16 of 42 in all the experiments) died of complications of gavage, but the weight gain of the remainder was at least as rapid as in the controls who received no supplements. After weaning, both groups received Oxoid breeders diet and water ad libitum. Neither a saline extract of the diet nor a filtrate of the supplementary feed inhibited agglutination of ovalbumin-coated red blood cells by a rat antiovalbumin antiserum; this confirms that they were ovalbumin free.

In one experiment, 2 adult ( $200 \mathrm{~g}) \mathrm{HL}$ female rats were immunised $(1.0 \mu \mathrm{g}$ of ovalbumin with pertussis

*Oxford Laboratory Animal Centre. 
adjuvant), and mated, and their litters were divided into supplement-fed and control groups; these were studied in a similar manner.

\section{Results}

In the first experiment, 7 of the 11 unsupplemented control HL rats (Animal Suppliers) immunised with the regimen (first dose of $1.0 \mu \mathrm{g}$ of ovalbumin) had IgE antiovalbumin antibody greater than the highest

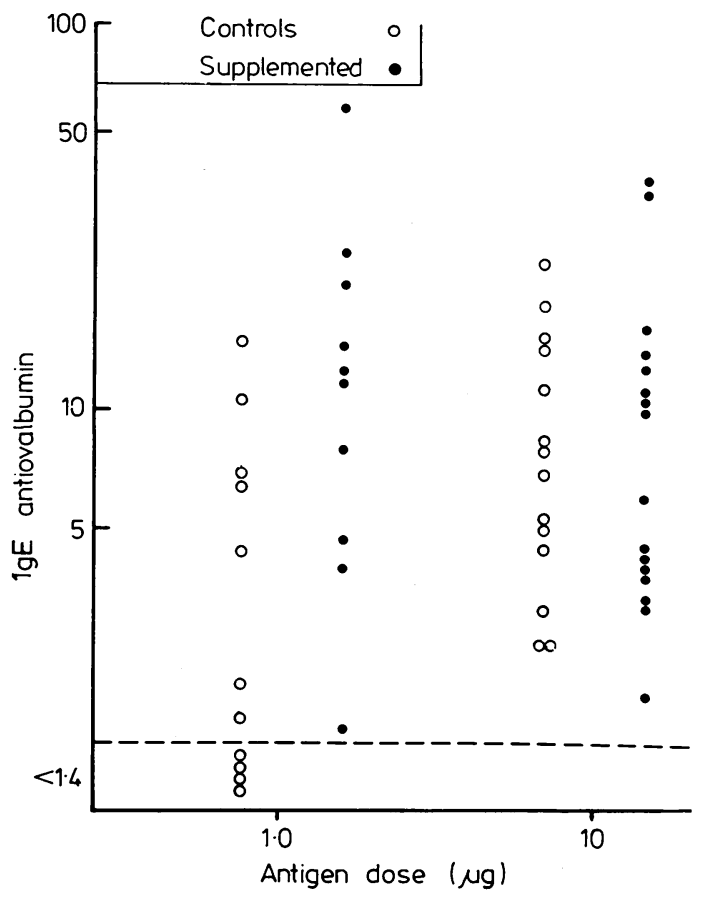

Fig. 1 IgEantiovalbumin antibody (counts bound by sample/counts bound by newborn rat serum) in 54-day-old rats, after immunisation with ovalbumin in dose of 1.0 or $10 \mu \mathrm{g}$, with adjuvant. Rats which had received cows' milk-based supplementary feeds and litter mates who did not are shown. The highest value observed in unimmunised rats $(1 \cdot 4)$ is indicated by the dotted line. value $(1 \cdot 4)$ observed in unimmunised adults. All 10 supplement-fed animals gave such values, and the median value was significantly higher than that of the unsupplemented controls (Fig. 1 and Table 1, experiment 1). This finding was confirmed in a second experiment with HL rats from OLAC (Table 1 , experiment 2). These differences did not result from the observed interlitter differences of IgE response. Fewer of the control rats had dithiothreitol-resistant haemaggluninating antiovalbumin antibody (presumed IgG) than did the supplement-fed animals (Fig. 2 and Table 1).

In 16 supplement-fed rats, and 14 controls injected with $10 \mu \mathrm{g}$ ovalbumin, the IgE responses were similar; the agglutinating antibody titre was

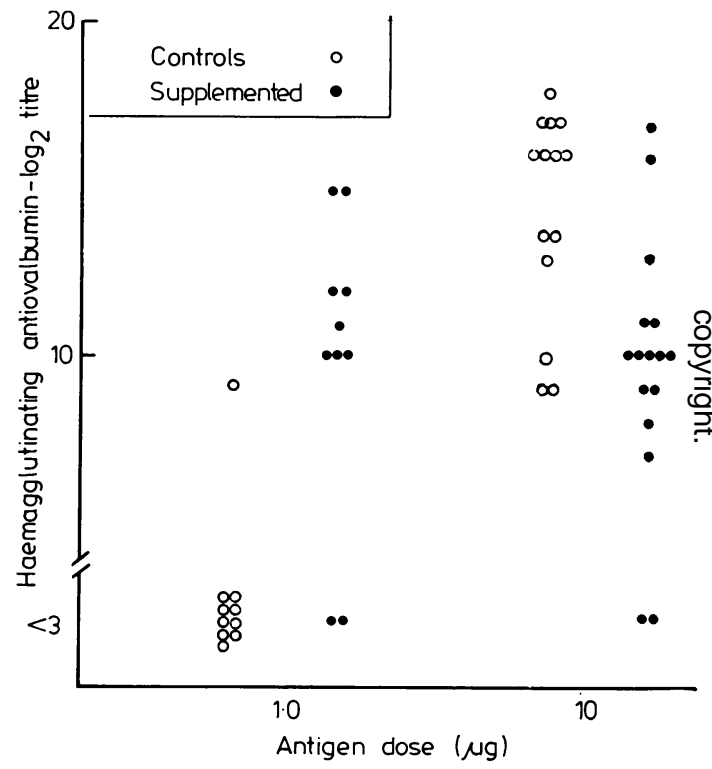

Fig. 2 Dithiothreitol-resistant haemagglutinating antiovalbumin antibody $\left(\log _{2}\right.$ titre $)$ in supplemented and control rats immunised as in Fig. 1.

Table 1 IgE and IgG antiovalbumin antibody in supplemented and control rat pups

\begin{tabular}{|c|c|c|c|c|c|c|c|c|c|c|c|c|}
\hline & \multicolumn{8}{|c|}{ Experiment 1} & \multirow{2}{*}{\multicolumn{4}{|c|}{$\frac{\text { Experiment } 2}{\text { IgE antiovalbumin* }}$}} \\
\hline & \multicolumn{4}{|c|}{ IgE antiovalbumin ${ }^{*}$} & \multicolumn{4}{|c|}{$\begin{array}{l}\text { Dithiothreitol-resistant } \\
\text { haemagglutinating antiovalbumin } \\
\text { antibody }-\log _{2} \text { titre }\end{array}$} & & & & \\
\hline & \multicolumn{2}{|l|}{$I \cdot O$} & \multicolumn{2}{|l|}{$10 \cdot 0$} & \multicolumn{2}{|l|}{$1 \cdot 0$} & \multicolumn{2}{|c|}{$10 \cdot 0$} & \multicolumn{2}{|l|}{$1 \cdot 0$} & \multicolumn{2}{|l|}{$10 \cdot 0$} \\
\hline & $S$ & $C$ & $S$ & $C$ & $S$ & $C$ & $S$ & $C$ & $S$ & $C$ & $S$ & $C$ \\
\hline $\begin{array}{l}\text { No of rats } \\
\text { Median } \\
\mathbf{P}\end{array}$ & $\begin{array}{l}10 \\
12 \cdot 0 \\
<0.01 \dagger\end{array}$ & $\begin{array}{l}11 \\
2 \cdot 1\end{array}$ & $\begin{array}{l}16 \\
7 \cdot 8 \\
\text { NS }\end{array}$ & $\begin{array}{l}14 \\
6.9\end{array}$ & $\begin{array}{l}10 \\
11 \\
0 \cdot 002 \ddagger\end{array}$ & $\begin{array}{l}11 \\
<3\end{array}$ & $\begin{array}{l}16 \\
10 \\
<0\end{array}$ & $\begin{array}{l}14 \\
16\end{array}$ & $\begin{array}{l}15 \\
8 \cdot 8 \\
<0.05\end{array}$ & $\begin{array}{l}13 \\
2 \cdot 6\end{array}$ & $\begin{array}{l}17 \\
5 \cdot 2 \\
\text { NS }\end{array}$ & $\stackrel{22}{5 \cdot 8}$ \\
\hline
\end{tabular}

*Counts bound/counts bound by newborn rat serum. $\uparrow$ Mann-Whitney U test, $\ddagger$ Fisher’s exact test.

$\mathrm{S}=$ supplemented, $\mathrm{C}=$ control. 
Table 2 IgE antiovalbumin responses to supplemented and suckled rat pups of immunised mothers

\begin{tabular}{lll}
\hline & $\begin{array}{l}\text { Supplementary feed } \\
(n=11)\end{array}$ & $\begin{array}{l}\text { Controls } \\
(n=13)\end{array}$ \\
\hline Median IgE antiovalbumin & $1 \cdot 25$ & 1.4 \\
Range & $1.0-1.85$ & $1.0-2 \cdot 3$ \\
\hline
\end{tabular}

significantly lower in the supplemented rats (Fig. 2 and Table 1). There was no significant correlation between IgE and IgG values in any of the groups ( $\mathrm{r}$ ranged from 0.15 to 0.22 ). The serum IgE concentration (median $0.61 \mu \mathrm{g} / \mathrm{ml}$ ) of 14 supplement-fed rats from both experiments in which animals were immunised with $1.0 \mu \mathrm{g}$ ovalbumin did not differ from their 17 controls (median IgE $0.7 \mu \mathrm{g} / \mathrm{ml}$ ).

IgE antiovalbumin antibody was detected (that is, it was greater than 1.4) in only 7 of the 13 rat pups fed by sensitised mothers, and the levels were significantly lower than the offspring of unsensitised mothers - that is, those immunised in experiment 1 $(\mathrm{P}<0.05$ Mann-Whitney $\mathrm{U})$; though this comparison is not strictly valid since these were not litter mates, this difference confirms the findings of Jarrett and Hall. ${ }^{5}$ Only 4 of 11 rat pups of sensitised mothers which received supplements gave IgE values greater than 1.4 , and the median values did not differ from those of the unsupplemented groups $(P>0.5$ Mann-Whitney U (Table 2).

\section{Discussion}

Our new finding, of increased IgE response after feeding cows' milk-based supplements, is antigen non-specific in that the response to ovalbumin was affected although the feed did not contain it. In this characteristic it is consistent with the clinical impression that the exacerbation of atopy which results from supplements of cows' milk feeds to human infants is antigen non-specific and unrelated to maternal sensitisation. The rat system is profoundly different from human atopy in that it depends on a dose-dependent adjuvantised injection of antigen, but the IgE antibody produced has similar skin sensitising characteristics as human IgE.

One possible mechanism for the antigen-nonspecific effect of supplements on the IgE response in human atopics is absorption of very low doses of normal environmental antigens, with increased amounts of endotoxin adjuvant resulting from the altered intestinal flora associated with the use of such supplements. ${ }^{10}$ It is possible that the increased IgE response resulted from other aspects of the experiment-such as the gavage-but the lack of such an effect in the experiment using a higher dose of antigen provides some control for this. The ideal control, gavaging with rat milk, was not possible. The considerable mortality of the gavaged rats is unlikely to explain the differences; if the deaths were anaphylactic, vulnerable animals would have been selected which would have reduced the effect presented. It is likely that such deaths were due to physical injury, observed in some, because most deaths occurred in the first week before sensitisation was likely to have developed.

In the group receiving the lower dose of ovalbumin, supplementation led to a similar higher IgG antibody response, but surprisingly supplements reduced the IgG response to the higher dose. An antigen non-specific decrease of IgG antibody production in mice has been shown after skin contact with antigen. ${ }^{11}$ In atopic humans both IgE and IgG antibody move together in response to a range of environmental allergens. ${ }^{12}$

This study strengthens the view that dietary supplements in suckling infants may have important immunological consequences, especially in those who are genetically vulnerable.

We thank Dr M W Turner for help in setting up the IgE antibody assays, Dr E E E Jarrett for IgE antibody and antiserum, and the Wellcome Research Laboratories for pertussis.

Financial support was provided by the Oxford Regional Health Authority and the Medical Research Council.

\section{References}

1 Matthew D J, Taylor B, Norman A P, Turner M W, Soothill J F. Prevention of eczema. Lancet 1977; i: 321-4.

2 Saarinen U M, Kajosaari M, Backman A, Siimes M A. Prolonged breast feeding as prophylaxis for atopic disease. Lancet 1979; ii: 163-6.

3 Saarinen U M, Björkstén F, Knekt P, Siimes M A. Serum IgE in healthy infants fed breast milk or cows' milk based formulas. Clin Allergy 1979; 9: 339-45.

4 Chandra R K. Prospective studies of the effect of breast feeding on incidence of infection and allergy. Acta Paediatr Scand 1979; 68: 691-4.

5 Jarrett E E E, Hall E. Selective suppression of IgE antibody responsiveness by maternal influence. Nature 1979; 280: 145-7.

- Karlsson T, Ellerson J R, Haig D M, Jarrett E E E, Bennich $H$. A radioimmunoassay for evaluation of the IgE and IgG antibody responses in the rat. Scand $J$ Immunol 1979; 9: 229-38.

7 Kofler R, Wick G. Some methodologic aspects of the chromium chloride method for coupling antigen to erythrocytes. J Immunol Methods 1977; 16: 201-9.

8 Olson R P, Weiblen B J, O'Leary J J, Moscowitz A J, McCullough J. A simple method for the inactivation of IgM antibodies using dithiothreitol. Vox Sang 1976; 30: 149-59.

9 Hall W G. Weaning and growth of artificially reared rats. Science 1975 ; 190 : 1313-5. 
10 Bullen C L, Tearle P V, Steward M G. The effect of 'humanised' milks and supplemented breast feeding on the faecal flora of infants. J Med Microbiol 1977; 10: 403-13.

11 Thomas W R, Watkins M C, Asherson G L. Reaginic antibody to contact sensitising agents; occurrence of cells which suppress IgG and not reagin responses. Immunology $1978 ; 35: 41-7$.

12 Platts-Mills $T$ A E, Snadjr M J, Ishizaka K, Frankland A W. Measurement of IgE antibody by an antigen-binding assay; correlation with $\mathrm{PK}$ activity and IgG and IgA antibodies to allergens. $J$ Immunol 1978; 120: 1201-10.

Correspondence to Professor J F Soothill, Department of Immunology, Institute of Child Health, 30 Guilford Street, London WC1N 1EH.

Received 31 March 1981

\section{The following articles will appear in future issues of this journal:}

Interpretation of arm circumference as an indicator of nutritional status I McDowell and F S King

Resuscitation of preterm babies at birth reduces the risk of death from hyaline membrane disease E Robson and E Hey

Retrolental fibroplasia-controlled study of 4 years' experience in a neonatal intensive care unit $V Y H Y u, D M H o o k h a m$, and J R M Nave

Metachromatic leucodystrophy-a review of 38 cases

$R$ MacFaul, N Cavanagh, B D Lake, $R$ Stephens, and A E Whitfield

Impact of home blood glucose monitoring on childhood diabetes

J H Baumer, A D Edelsten, B C Howlett, C Owens, C A Pennock, and D C L Savage

Whole foods and increased dietary fibre improve blood glucose control in diabetic children A-L Kinmonth, $R M$ Angus, $P$ A Jenkins, $M$ A Smith, and $J$ D Baum

Single dose trimethoprim-sulphamethoxazole treatment of symptomatic urinary infection WR Pitt, S A Dyer, J L McNee, and J R Burke 